\title{
Interactive E-Module for Science Learning Content: Validity and Feasibility
}

Ni Putu Sintawati ${ }^{*}$, I Gede Margunayasa ${ }^{2}$

1,2,3 Program Studi Pendidikan Guru Sekolah Dasar, Universitas Pendidikan Ganesha, Singaraja, Indonesia

\section{A R T I C L E I N F O \\ Article history: \\ 25 December 2020 \\ Received in revised form \\ 01 January 2021 \\ Accepted 25 January \\ 2021 \\ Available online 03 \\ Pebruari 2021 \\ Kata Kunci: \\ E-Modul Interaktif, IPA}

Keywords:

Nteractive E-Modul,

Science

\begin{abstract}
A B S T R A K
Kurangnya penggunanan dan pengembangan bahan ajar, khususnya pada muatan IPA yang menyebabkan kegiatan pembelajaran tidak berjalan dengan optimal. Penelitian ini bertujuan untuk mengembangkan e-modul interaktif bermuatan IPA yang sudah teruji validitasnya. Penelitian pengembangan ini menggunakan model pengembangan ADDIE yang terdiri dari lima tahapan, yaitu analisis, desain, pengembangan, implementasi, dan evaluasi. Namun, penelitian ini hanya dilaksanakan sampai tahap pengembangan saja, tahap implementasi dan evaluasi tidak dilaksanakan karena keterbatasan waktu, sumber daya, dan finansial yang disebabkan oleh kondisi pandemi saat ini. Subjek dalam penelitian ini adalah e-modul interaktif bermuatan IPA, sedangkan objek dalam penelitian ini adalah validitas emodul interaktif bermuatan IPA. Penelitian pengembangan ini menggunakan metode kuesioner dengan menyebarkan lembar penilaian kepada responden yaitu, ahli materi, ahli media, dan praktisi. Hasil uji validitas e-modul interaktif muatan IPA ini berupa angka yang dihitung rata-rata skornya kemudian dikategorikan ke dalam tabel pedoman skala lima. Penilaian dua orang dosen ahli materi memperoleh ratarata skor 4,5 dengan kualifikasi sangat baik. Penilaian dua orang dosen ahli media
\end{abstract} memperoleh rata-rata skor 4,8 dengan kualifikasi sangat baik dan hasil penilaian praktisi yang terdiri dari dua orang guru wali kelas V SD memperoleh rata-rata skor 4,9 dengan kualifikasi sangat baik. Berdasarkan hasil analisis yang diperoleh maka dapat disimpulkan bahwa e-modul interaktif bermuatan IPA termasuk kualifikasi sangat baik.

\begin{abstract}
A B S T R A C T
Lack of use and development of teaching materials, especially in science content, which causes learning activities not to run optimally. This study aims to develop an interactive e-module with science content that has been tested for validity. This development research uses the ADDIE development model which consists of five stages, namely analysis, design, development, implementation, and evaluation. However, this research was only carried out until the development stage, the implementation and evaluation stages were not carried out due to time, resource and financial limitations caused by the current pandemic conditions. The subject in this study was an interactive e-module with science content, while the object in this study was the validity of an interactive e-module with science. This development research uses a questionnaire method by distributing assessment sheets to respondents, namely, material experts, media experts, and practitioners. The results of the validity test of the interactive e-module on the IPA content are in the form of numbers that are calculated as the average score then categorized into the five scale guideline table. The assessment of two material expert lecturers obtained an average score of 4.5 with very good qualifications. The assessment of two media expert lecturers obtained an average score of 4.8 with very good qualifications and the results of the practitioner's assessment consisting of two homeroom teachers in grade V SD obtained an average score of 4.9 with very good qualifications. Based on the results of the analysis obtained, it can be concluded that the interactive e-module with science content is very good qualifications.
\end{abstract}

\section{Introduction}

Science learning is one of the learning content that must be studied in primary school education. The science learning process at the elementary school level focuses not only on understanding knowledge but also on understanding scientific attitudes and techniques so that the learning process becomes fun and can improve students' critical thinking skills in developing knowledge and understanding of the natural environment and its surroundings (Rubini et al., 2018; Saripudin et al., 2018). Science learning must also be developed to be student-centered, which involves student activeness in the learning process 
to explore their potential, improve problem-solving abilities and build curiosity in every learning activity (Sulthon, 2017; Taqiyyah et al., 2017). It will be achieved optimally if the science learning process in elementary schools uses various learning components, teaching materials. Multiple efforts have been made to optimize elementary school science learning, a learning process that involves student activeness and the need to use exciting teaching materials and following the characteristics of students to improve student learning outcomes and motivation independently (Pratama et al., 2019; Puspita, 2019; Susilowati, 2017). In addition, teaching materials must also be developed with various innovations following the development of technology (Suzuki et al., 2020).

However, in reality, the use and development of teaching materials, especially in science content, have not been implemented optimally. At the same time, the learning process in primary schools requires the use of various teaching materials to support the learning process. The problems that often occurred in science learning are: (1) the learning process is still teacher-centered. It means that the teacher delivers more material so that the communication process is one-way, (2) the lack of interesting teaching materials, for example, the teacher only uses textbooks that are in the form of student books and worksheets in delivering material, (3) limited material in textbooks which causes a lack of student interest in learning the material (Fitria \& Idriyeni, 2017; Laksana, 2016). In addition, the learning process is currently being carried out online due to the Covid-19 pandemic, which causes teachers and students not to be able to carry out the learning process face-to-face, like in class (Herliandry et al., 2020; Jogezai et al., 2021). Various efforts have been implemented in the distance learning process regarding learning methods and models, such as WhatsApp, Zoom Meetings, Google Meet, and Google Classroom (Abidah et al., 2020; Qazi et al., 2021). In addition, teachers use more teaching materials in handbooks, such as student books, in delivering material or giving assignments in the form of text or images to students sent via WhatsApp (Kusuma \& Hamidah, 2020).

It is supported by the observations of the fifth-grade student book theme 6, which showed that the material in student books, especially on science content, is still minimal. Questionnaires were distributed to teachers on November $9^{\text {th }}$ to $11^{\text {th }} 2020$, in the fifth grade of SD Cluster II, Kecamatan Buleleng. The results were (1) $100 \%$ of teachers stated that they always use student books in online learning activities, (2) 77, $8 \%$ of teachers stated that the flexibility of science content material in student books was still narrow, (3) $77.8 \%$ of teachers stated that the material content of science content in student books was lack, (4) $88.9 \%$ of teachers stated that the completeness of the material in science content in student books on sub-theme 1 theme 6 was incomplete, (5) $100 \%$ of teachers stated that the science content material in student books on sub-theme 1 theme 6 needs to be developed. Teaching materials that only use student books have several weaknesses, not describing the conditions in real terms. The learning process is less effective and does not activate students. The material is minimal. It is often considered memorization material. It makes students difficult to understand the material and tend to be bored in learning activities (Rostikawati \& Permanasari, 2016). The superficiality of the teaching materials in student books also impacts the narrowness of students' insights and knowledge. It causes interest and learning outcomes to decrease, and learning becomes meaningless and not optimal. Students are required to have better learning abilities in terms of knowledge and creativity.

If these problems continue, it is necessary to make an alternative solution that is considered effective and innovative in overcoming these limitations in the learning process. The answer is to develop teaching materials that collaborated with science and technology. Interactive e-module teaching materials in electronic form can help students develop their knowledge in learning material and improve students' independent learning, both in class and distance learning. Teachers in learning are only facilitators and mediators. (Aprilia \& Suryadarma, 2020; Boyd, 2019). An e-module is beneficial for students because it contains clear objectives, subject matter, activity sheets and can check students' understanding independently (Citrawathi et al., 2016). Interactive e-module is also considered effective teaching materials and can increase students' interest in learning (Neppala et al., 2018). The interactive e-module was chosen because it has several advantages compared to the printed module. It is equipped with images, animation, audio, and video that are following the material. Students are motivated and more active in learning activities, such as observing pictures, videos, listening to the audio, and takes formative tests/quizzes that allow for immediate automated feedback (Herawati \& Muhtadi, 2018; Imansari \& Sunaryantiningsih, 2017; Suarsana \& Mahayukti, 2013).

This development research is supported by several researchers, namely Koderi (2017) stated that the SAVI-based e-module for learning Arabic at MTs can effectively improve student learning outcomes, so that it has a positive impact on improving student learning achievement. Asrial et al., (2020) stated that ethnocontructivism e-module with the help of the 3D Pageflip application for fifth grade elementary school students is very suitable to use in the learning process because it has an attraction for students, so it can foster perceptions, interests, and motivation to learn. Logan et al., (2021) stated that e-module 
based on e-learning is an innovative teaching strategy to improve the success of learning outcomes and is able to direct students to be more prepared and actively involved in learning. Ningsih \& Mahyuddin, (2021) explained that thematic e-module based on early childhood politeness in kindergarten with Kvsoft Flipbookmaker software application are valid, practical and effective in use because they have a display of material that is equipped with examples of pictures, and varied writing.

The results of the study which is conducted by Astra et al., (2020) showed that the e-physics module with a creative problem solving model that is equipped with HOTS questions on the kinetic theory material of gas is suitable to be applied as an independent teaching material and can improve students' higher order thinking skills. Syahroni et al., (2016) showed that the e-module in the form of a digimon (science digital module) has a strong influence on student independence and learning outcomes because this e-module uses technology that is equipped with animation and video which functions to make it easier for students to understand the material. Hamid et al., (2021) explained that the e-content module for chemical content can be used as a guide and resource for educators and students in the chemistry learning process on the blended learning platform or flipped classroom because this product shows a high level of perception in content, design, usability, and construction effectiveness. Setiyani et al., (2020) mentioned that the digital module based on mathematical communication skills is very valid because this digital module has the ability to foster student independence in learning and its use is not limited to the classroom. In line with this, it is necessary to research the development of teaching materials in interactive e-modules to be actively and independently involved in the learning process. In addition, it can also be used as an alternative in teaching and creating active, creative, and innovative learning so that students get new learning experiences, are not boring, do not depend on teachers, and can improve student learning outcomes.

This study aims to develop a science interactive e-module on sub-theme 1 theme 6 in fifth-grade elementary school whose validity has been tested. The interactive e-module developed in this study is different from the previously developed e-module. The difference lies in the content of the material taken, the content of science in sub-theme 1 theme 6 in the fifth grade of elementary school. This e-module developed uses the Canva software application that is easily accessible to students and uses an attractive material display equipped with moving text, images, audio, video, and interactive questions directly connected to Google Form.

\section{Method}

This research was science interactive e-module development research on sub-theme 1 theme 6 in fifth-grade elementary schools using the ADDIE development model. This development model consists of 5 stages, (1) analysis, (2) design, (3) development, (4) implementation, and (5) evaluation (Rubini et al., 2018). However, this research was only carried out until the development stage. The implementation and evaluation stages were not carried out due to time, resource, and financial limitations caused by the Covid-19 pandemic. (1) The analysis phase started from needs analysis, student characteristics analysis, curriculum analysis, and interactive e-module analysis. A needs analysis was carried out by distributing questionnaires to teachers to determine the information needed in the learning process, especially in learning science content on sub-theme 1 theme 6 . Analysis of student characteristics was carried out to analyze students in terms of levels of cognitive development in the use of interactive e-module. Curriculum analysis was carried out by analyzing core competencies, basic competencies, and indicators in fifth-grade science content sub-theme 1 theme 6 , so that later they can be used as guidelines in developing material in the form of interactive e-modules. The analysis resulted in a science interactive emodule on temperature and heat. The interactive e-module analysis was carried out to find out and collect information related to the criteria for a good interactive e-module to be used as a reference in developing a science interactive e-module. (2) The design stage was carried out by making science interactive emodule design on sub-theme 1 theme 6 in fifth-grade elementary school. This stage begins with determining the overall interactive e-module design, starting from creating an interactive e-module cover design, compiling material to practice questions on the last page of the interactive e-module. This interactive e-module was designed using Canva software and then consulted with the supervisor to get suggestions or input to improve. (3) The development stage was carried out by developing an interactive e-module following the discussion and suggestions from the supervisor. After the interactive e-module has been developed, material experts, media experts, and practitioners carry out the validity test. Product trials in interactive e-module were carried out to determine the validity of interactive e-modules through the review from material experts, media experts, and practitioners. Then the data from the material experts, media experts, and practitioners were analyzed and revised according to the data obtained. 
The subjects in this study were science interactive e-module products on sub-theme 6 themes 1 in fifth-grade elementary schools and experts who were competent in their fields. The experts consist of two material expert lecturers in science content, two media expert lecturers who provide reviews of the media developed, and two fifth grade homeroom teachers as practitioners. At the same time, the object in this study was the validity of the interactive e-module that was developed. The research data were obtained from two types of data, qualitative data and quantitative data. Qualitative data were obtained from expert reviews. The data can be in the form of responses, input, or criticism. At the same time, quantitative data is data in the form of scores obtained from interactive e-module assessment sheets based on expert test reviews. Collecting data in this study used a questionnaire method. The data collection instrument used was a rating scale in an interactive e-module assessment sheet using 1-5 scale (Ilhami \& Rimantho, 2017). This interactive e-module validity sheet instrument includes 7 aspects, : (a) organization, (b) attractiveness, (c) letters and images, (d) self-instruction, (e) self-contained, (f) adaptive, and ( g) user friendly (Purnomo \& Wilujeng, 2016). The grid for the science interactive e-module validation showed in Tables 1,2 , and 3 .

Table 1. Material Expert Test Instrument

\begin{tabular}{|c|c|c|c|c|}
\hline No & Aspect & Indicator & Number & Total \\
\hline \multirow[t]{7}{*}{1} & Self- & Clarity of learning objectives & 1,2 & 2 \\
\hline & Instruction & Packaging of learning materials & $3,4,5$ & 3 \\
\hline & & $\begin{array}{l}\text { Learning materials are supported by examples and } \\
\text { illustrations }\end{array}$ & $6,7,8$ & 3 \\
\hline & & $\begin{array}{l}\text { The exercises presented are relevant to the material, } \\
\text { the context of the activities, and the environment of } \\
\text { the students }\end{array}$ & $9,10,11,12,13$ & 5 \\
\hline & & Use simple and communicative language & $14,15,16$ & 3 \\
\hline & & Availability of a summary of learning materials & 17 & 1 \\
\hline & & Availability of feedback on student assessments & 18,19 & 2 \\
\hline 2 & Self Contained & $\begin{array}{l}\text { Contains all learning materials one standard } \\
\text { competency or basic competence in its entirety }\end{array}$ & 20,21 & 2 \\
\hline 3 & Adaptive & $\begin{array}{l}\text { The interactive e-module adapts to technological } \\
\text { developments }\end{array}$ & 22,23 & 2 \\
\hline \multirow[t]{2}{*}{4} & User Friendly & Instructions are easy to use & 24,25 & 2 \\
\hline & & Information is easy to use & 26,27 & 2 \\
\hline
\end{tabular}

Table 2. Media Expert Test Instrument

\begin{tabular}{|c|c|c|c|c|}
\hline No & Aspect & Indicator & Number & Total \\
\hline \multirow[t]{2}{*}{1} & Organization & Ease of achieving learning goals & 1 & 1 \\
\hline & & Clarity of learning material & 2 & 1 \\
\hline \multirow[t]{3}{*}{2} & Attractiveness & $\begin{array}{l}\text { The attractiveness of the appearance of the contents } \\
\text { of the science interactive e-module }\end{array}$ & 3,4 & 2 \\
\hline & & Clarity of instructions for doing practice questions & 5 & 1 \\
\hline & & The neatness of the science interactive e-module & 6 & 1 \\
\hline \multirow[t]{2}{*}{3} & Letters and & The correct color of letters and images & 7,8 & 2 \\
\hline & pictures & Clarity of use of letters & 9 & 1 \\
\hline \multirow[t]{2}{*}{4} & User Friendly & Instructions are easy to use & 10,11 & 2 \\
\hline & & Information is easy to use. & 12,13 & 2 \\
\hline 5 & Adaptive & $\begin{array}{l}\text { The science interactive e-module adapts to } \\
\text { technological developments. }\end{array}$ & 14,15 & 2 \\
\hline
\end{tabular}

Table 3. Practitioner Test Instrument

\begin{tabular}{cclcc}
\hline No & Aspect & \multicolumn{1}{c}{ Indicator } & Number & Total \\
\hline 1 & Organization & $\begin{array}{l}\text { Ease of achieving learning goals } \\
\text { Clarity of learning material }\end{array}$ & 1 & 1 \\
2 & Attractiveness & $\begin{array}{l}\text { The attractiveness of the appearance of the contents } \\
\text { of the science interactive e-Module } \\
\text { Clarity of instructions for doing practice questions }\end{array}$ & 3,4 & 1 \\
& & & 5 & 1
\end{tabular}




\begin{tabular}{|c|c|c|c|c|}
\hline No & Aspect & Indicator & Number & Total \\
\hline & & The neatness of the Science Interactive e-Module & 6 & 1 \\
\hline \multirow[t]{2}{*}{3} & Letters and & The correct color of letters and images & 7,8 & 2 \\
\hline & pictures & Clarity of use of letters & 9 & 1 \\
\hline \multirow[t]{7}{*}{4} & Self & Clarity of learning objectives & 10,11 & 2 \\
\hline & Instruction & Packaging of learning materials & $12,13,14$ & 3 \\
\hline & & $\begin{array}{l}\text { Learning materials are supported by examples and } \\
\text { illustrations }\end{array}$ & $15,16,17$ & 3 \\
\hline & & $\begin{array}{l}\text { The exercises presented are relevant to the material, } \\
\text { the context of the activities, and the environment of } \\
\text { the students }\end{array}$ & $18,19,20,21,22$ & 5 \\
\hline & & Use simple and communicative language & $23,24,25$ & 3 \\
\hline & & Availability of a summary of learning materials & 26 & 1 \\
\hline & & Availability of feedback on student assessments & 27,28 & 2 \\
\hline 5 & Self-Contained & $\begin{array}{l}\text { Contains all learning materials one standard } \\
\text { competency or basic competence in its entirety }\end{array}$ & 29,30 & 2 \\
\hline \multirow[t]{2}{*}{6} & User Friendly & Instructions are easy to use & 31,32 & 2 \\
\hline & & Information is easy to use & 33,34 & 2 \\
\hline 7 & Adaptive & $\begin{array}{l}\text { The interactive e-module adapts to technological } \\
\text { developments }\end{array}$ & 35,36 & 2 \\
\hline
\end{tabular}

The instrument used must be valid before being tested in this development research. Therefore, the judges (experts) test the validity of the contents of the instrument following their fields. The content validity test in this study used the Gregory formula. The content validity test showed that the content validity coefficient of the material, media, and interactive e-module expert's assessment instruments = 1.00. The results of the content validity test showed that the content validity of the interactive e-module assessment instrument from the material, media, and practitioner experts was in a very high validity category.

Methods and data analysis techniques used in this research were qualitative descriptive analysis methods and quantitative descriptive analysis. The qualitative descriptive analysis method is used to process data in sentences or words, or categories regarding an object (Agung, 2014). The qualitative descriptive analysis method was used to process data in the form of input, criticism, responses, and suggestions from the results of reviews by material experts, media experts, and practitioners on products developed through the distribution of interactive e-module assessment sheets. In contrast, the quantitative descriptive analysis method was used to obtain an average. The average score of each expert, material experts, media experts, and practitioners related to the interactive e-module being developed. The average score obtained through the interactive e-module assessment sheet was analyzed and converted into a five-scale conversion guideline. The indicator of success in this study was the average interactive e-module validation score, at least in the good category with a range of $3.0<x \leq 4.0$.

\section{Result and Discussion}

\section{Results}

The analysis stage consisted of needs analysis, curriculum analysis, student characteristics analysis, and good interactive e-module criteria analysis. A needs analysis was carried out by giving questionnaires to fifth-grade teachers at SD Cluster II, Kecamatan Buleleng, to determine the needs needed in the learning process, especially in science, sub-theme 1 theme 6 . The needs analysis results showed that $100 \%$ of teachers stated that they always use books for online learning activities. $88.9 \%$ of teachers stated that the completeness of the science content material in student books on sub-theme 1 theme 6 was incomplete. $100 \%$ of teachers stated that they had never made an interactive e-module in delivering theory. Therefore, the development of science interactive e-module on sub-theme 1 theme 6 . Curriculum analysis was carried out by analyzing core competencies, basic competencies, and determining indicators of competency achievement in science content sub-theme 1 theme 6 fifth grade and learning objectives to serve as benchmarks in developing a science interactive e-module. Analysis of student characteristics was carried out to analyze students' cognitive development levels using an interactive e-module. Analysis of student characteristics showed that elementary school students prefer to use concrete objects by displaying attractive images, viewing videos, and listening to audio. Students were happier to be directly involved in the learning process. According to Piaget's development theory, elementary school children are between 7-11 years (Ibda, 2015). A good interactive e-module analysis is 
used to analyze the criteria for a good interactive e-module, so it is suitable for elementary school children. The interactive e-module developed is guided by 7 aspects, : (a) organization, (b) attractiveness, (c) letters and images, (d) self-instruction, (e) self-contained, (f) adaptive, and (g) user-friendly (Purnomo \& Wilujeng, 2016).

After the analysis stage, then proceed with the design stage, which was carried out by designing an interactive e-module. It begins by determining the material contained in sub-theme 1 theme 6 Basic Competency 3.6, applying the concept of heat transfer in everyday life, and designing the cover until the contents of the interactive e-module. This science interactive E-Module was developed using Canva software on A4 paper measuring $21 \mathrm{~cm} \times 29.7 \mathrm{~cm}$. The interactive e-module design consulted with the supervisor to get input and suggestions to make improvements. After being approved by the supervisor, then proceed to the development stage.

The development stage is carried out by developing an interactive e-module adjusted to the supervisor's design. The interactive E-Module developed with covers, preface, table of contents, basic competencies, achievement indicators, learning objectives, instructions, content/material with attractive images, audio, video, summary, and exercises.

The science interactive e-module display in sub-theme 1 theme 6 in fifth-grade elementary schools developed can be seen in Figure 1.

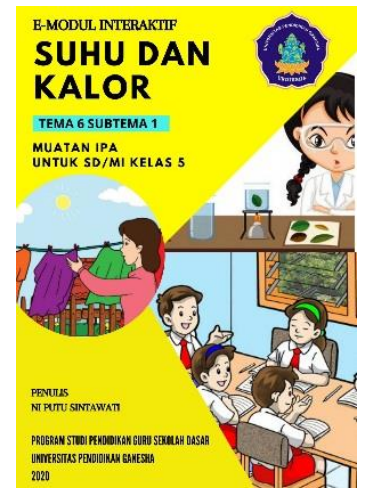

(a) Interactive E-Module Cover

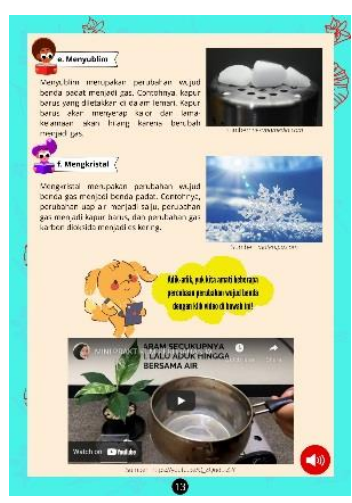

(b) Content/Material of Interactive E-Module

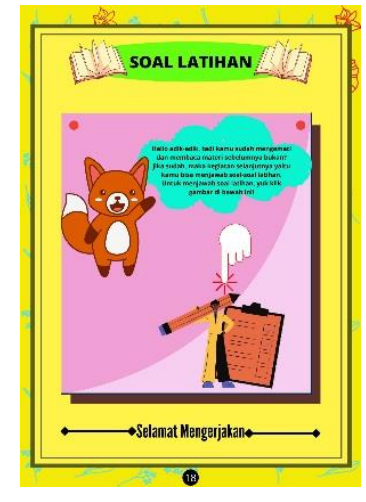

(c) Exercises

Figure 1. Interactive E-Module

After the interactive e-module has been developed, the next step was to carry out an interactive emodule trial to determine the interactive e-module's validity. This interactive e-module validity test was conducted by two material expert lecturers, two media expert lecturers, two practitioners, and the fifthgrade homeroom teacher.

The validity of the science interactive e-module on sub-theme 1 theme 6 in fifth-grade elementary schools was presented in Figures 2, 3, and 4.

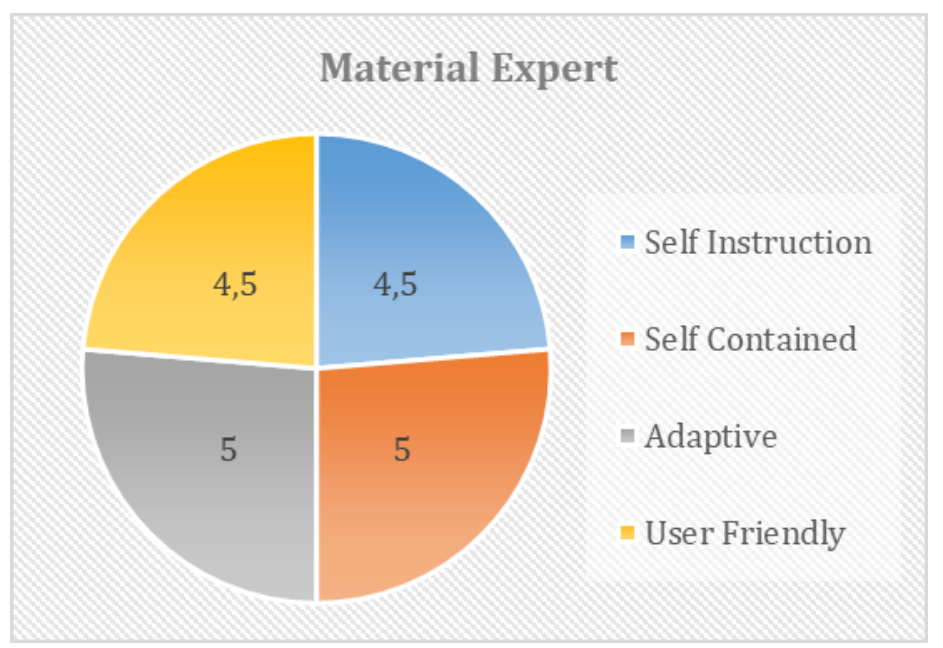

Figure 2. The Average Score of Each Indicator of Material Expert Judgment 
Figure 2 showed the results that Self Instruction got an average score of 4.5. Self-Contained got an average score of 5 . Adaptive got an average score of 5, and User Friendly got an average score of 4.5. It can be seen that each indicator point for the evaluation of the validity of the science interactive e-module was in the range of $4.0<X \leq 5.0$, according to the five scale conversion guidelines, it was very good. From this, the overall science content interactive e-module was 4.5 , so the science content interactive e-module was very well qualified.

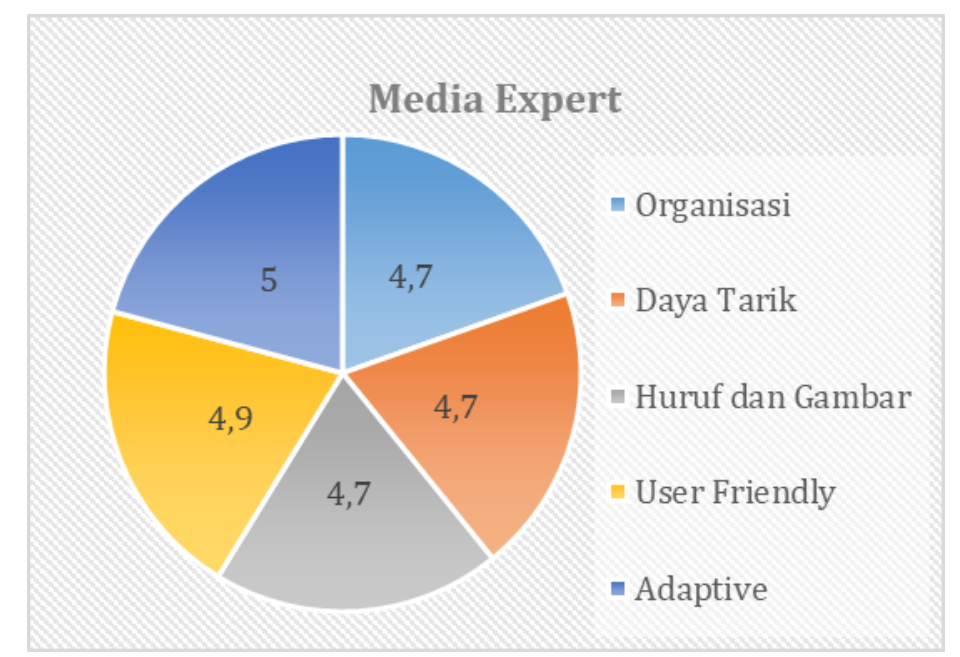

Figure 3. The Average Score of Each Indicator of The Media Expert's Assessment

Figure 3 showed that the Organization obtained an average score of 4.7. Attractiveness obtained an average score of 4.7. Letters and pictures got an average score of 4.7, User Friendly got an average score of 4.9, and Adaptive got an average score of 5. According to the five scale conversion guidelines, each of the indicators for the evaluation items of the science interactive e-module validity was in the range of $4.0<\mathrm{X} \leq 5.0$. It included very good qualifications. The overall average validity score of media experts was 4.8, so the Interactive Science Content E-Module was very well qualified.

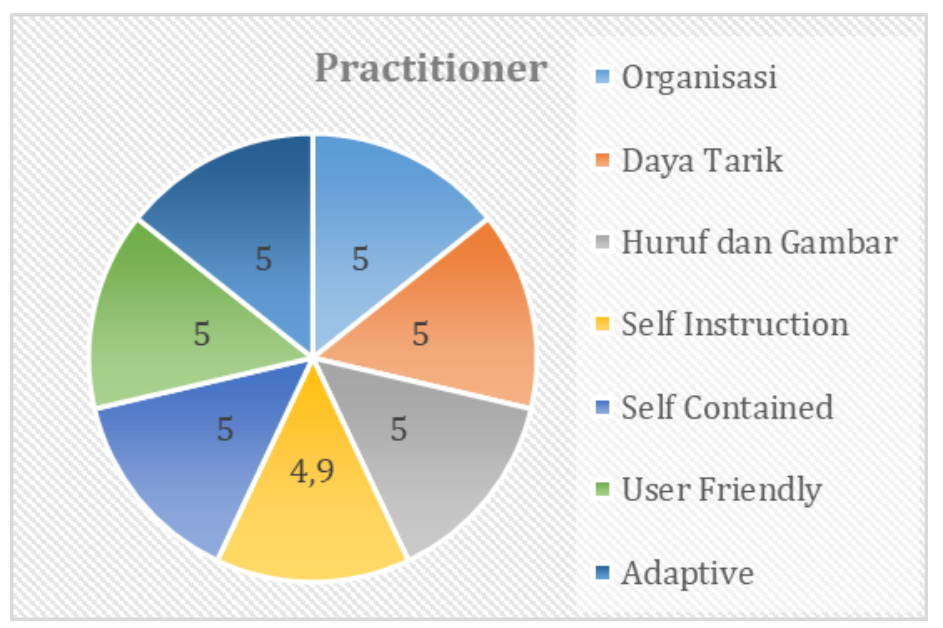

Figure 4. The Average Score of Each Practitioner Assessment Indicator

Figure 4 showed the results that the Organization got an average score of 5 . Attractiveness got an average score of 5. Letters and pictures got an average score of 5. Self Instruction gets an average score of 4.9. Self Contained gets an average score 5. User Friendly got an average score of 5. Adaptive got an average score of 5 . According to the five scale conversion guidelines, each indicator for the science interactive e-module validity assessment was in the range of $4.0<\mathrm{X} \leq 5.0$, according to the five scale conversion guidelines classified as very good. From this, the overall average score of the validity of the practitioners was 4.9 , so the science interactive e-module was very well qualified. 


\section{Discussion}

The interactive e-module developed was said to be very good because it fulfills all aspects. In terms of material, it showed that the interactive e-module developed contains aspects of self-contained and self-instruction. The self-contained aspect showed that students could learn the material thoroughly because science content in basic competencies was included in an interactive e-module developed. The self-instruction aspect showed that students could easily learn actively and independently because the learning objectives in this interactive e-module follow the competencies achieved. The material was equipped with images, videos, and audio relevant to the participants' material and characteristics. It is also in line with Piaget's theory about cognitive development. It stated that elementary school-age children could solve problems and think systematically about concrete objects and examples so that children can only solve real or are absorbed by their five senses, not concrete abstracts. Students will have difficulty solving a problem (Juwantara, 2019). Therefore, elementary school-age children can be facilitated by an interactive e-module that has been developed. The interactive e-module can make students interact directly, such as actively observing pictures, actively reading material, observing colored or moving writing, listening to sounds, animations, and even videos and films, so that students get new and meaningful learning experiences (Hamdunah et al., 2016; Sidiq \& Najuah, 2020).

In addition, when viewed from the quality and appearance of the media, it showed that the interactive e-module contains user-friendly and adaptive aspects. The user-friendly aspect showed that the developed interactive e-module could make students more familiar with its use. It contains material and instructions for simple, communicative, and clear language, making it easy for students to understand. The research conducted by Noroozi \& Mulder (2017) showed that the use of e-modules that use grammar and sentences that are easy to understand, clear and communicative, can encourage learning motivation, increase student understanding of the material and have a positive impact on student satisfaction with the learning experience. Meanwhile, the adaptive aspect showed that the interactive e-module could adapt to technological developments and is flexible, such as the e-module material for science content in subtheme 1 theme 6 can be learned and accessed easily via a laptop or smartphone so that students are more active and independent both in school and at home. These results are in line with the results of research conducted by Bakri et al., (2016); Wijayanti et al., (2016) stated that the web-based e-module is very good and suitable to use to increase the achievement of students' knowledge competencies and can be accessed anywhere and anytime via a laptop with internet network. Research result Suryanda et al., (2016) also stated that the Android-based multimedia mobile learning module that can be accessed using a smartphone could improve student learning outcomes and learn independently.

The interactive e-module with science on sub-theme 1 theme 6 was developed and designed using Canva software, is also exciting to use by students because there is a fascinating depiction of e-module content on each new slide/page that begins with a cover, Basic Competencies, learning indicators, learning objectives, instructions, explanation of material to practice questions. The attractiveness, such as letters and images, varies according to elementary school students' characteristics. It is in line with research conducted by Asrial et al., (2020), which stated that the use of ethnocontructivism e-module in the learning process was in a very good and suitable category for fifth-grade elementary school learning so that it has a positive impact on students' perceptions, interests, and motivation. Suarsana \& Mahayukti, (2013) stated that using an e-module, which contains practice questions and answer keys, was a very good quality in improving critical thinking skills. In addition, students can also find out their weaknesses so that learning becomes meaningful for students. Based on some of the research results that have been carried out before, it is believed that the science interactive e-module on sub-theme 1 theme 6 in fifthgrade elementary school was very good and suitable to be implemented in the learning process. In addition, the interactive e-module developed can also help teachers in teaching and allow students to be actively involved in the learning process so that learning becomes more meaningful, learning objectives can be achieved optimally and had a good impact on student learning outcomes, interests, and motivation.

\section{Conclusion}

From the discussion, it can be concluded that the science interactive e-module product on subtheme 1 theme 6 in fifth-grade elementary schools is in very good qualifications. The interactive e-module developed is suitable for use in the learning process because it has an attractive quality and appearance, easy to use, flexible, and follows student characteristics and learning objectives. In addition, the interactive e-module developed can also help teachers in teaching and allow students to be actively involved in the learning process so that learning becomes more meaningful, learning objectives can be achieved optimally and had a good impact on student learning outcomes, interests, and motivation. 


\section{References}

Abidah, A., Hidaayatullaah, H. N., Simamora, R. M., Fehabutar, D., \& Mutakinati, L. (2020). The Impact of Covid-19 to Indonesian Education and Its Relation to the Philosophy of "Merdeka Belajar." Studies in Philosophy of Science and Education, 1(1), 38-49. https://doi.org/10.46627/sipose.v1i1.9.

Agung, A. A. G. (2014). Metodologi Penelitian Pendidikan. Aditya Media Publishing.

Aprilia, I., \& Suryadarma, I. G. P. (2020). E-Module of Mangrove Ecosystem (EMME): Development, Validation, and Effectiveness in Improving Students' Self-Regulated. Biosfer : Jurnal Pendidikan, 13(1), 114-129. https://doi.org/10.21009/biosferjpb.v13n1.114-129.

Asrial, Syahrial, Maison, Kurniawan, D. A., \& Piyana, S. O. (2020). Ethnoconstructivism E-Module to Improve Perception, Interest, and Motivation of Students in Class V Elementary School. JPI Jurnal Pendidikan Indonesia), 9(1), 30-41. https://doi.org/10.23887/jpi-undiksha.v9i1.19222.

Astra, I. M., Raihanati, R., \& Mujayanah, N. (2020). Development of Electronic Module Using Creative Problem-Solving Model Equipped with Hots Problems on The Kinetic Theory of Gases Material. Jurnal Penelitian \& Pengembangan Pendidikan Fisika, 6(2), 181-194. https://doi.org/10.21009/1.06205.

Bakri, F., Siahaan, B. Z., \& Permana, A. H. (2016). Rancangan Website Pembelajaran Terintegrasi dengan Modul Digital Fisika Menggunakan 3D PageFlip Professional. Jurnal Penelitian \& Pengembangan Pendidikan Fisika, 2(2), 113-118. https://doi.org/10.21009/1.02215.

Boyd, L. (2019). Using Technology-Enabled Learning Networks to Drive Module Improvements in the UK OpenUniversity. Journal of Interactive Media in Education, 2019(1), 1-7. https://doi.org/10.5334/jime.529.

Citrawathi, D. M., Adnyana, P. B., \& Santiasa, M. P. A. (2016). Analisis Kebutuhan Untuk Pengembangan Modul Inkuiri Berbasis Pertanyaan (MIBP) Di SMP. JPI (Jurnal Pendidikan Indonesia), 5(1), 1-11. https://doi.org/10.23887/jpi-undiksha.v5i1.8289.

Fitria, Y., \& Idriyeni, I. (2017). Development of Problem-Based Teaching Materials for The Fifth Graders of Primary School. Jurnal Ta'dib, 20(2), 99-106. http://dx.doi.org/10.31958/jt.v20i2.747.

Hamdunah, Yunita, A., Zulkardi, \& Muhafzan. (2016). Development a Constructivist Module and Web on Circle and Sphere Material with Wingeom Software. Journal on Mathematics Education, 7(2), 109116. https://doi.org/10.22342/jme.7.2.3536.109-116.

Hamid, S. N. M., Lee, T. T., Taha, H., Rahim, N. A., \& Sharif, A. M. (2021). E-Content Module For Chemistry Massive Open Online Course (Mooc): Development And Students' Perceptions. Journal of Technology and Science Education, 11(1), 67-92. https://doi.org/10.3926/jotse.1074.

Herawati, N. S., \& Muhtadi, A. (2018). Pengembangan Modul Elektronik (E-Modul) Interaktif Pada Mata Pelajaran Kimia kelas XI SMA. Jurnal Inovasi Teknologi Pendidikan, 5(2), 180-191. https://doi.org/10.21831/jitp.v5i2.15424.

Herliandry, L. D., Nurhasanah, Suban, M. E., \& Heru, K. (2020). Pembelajaran Pada Masa Pandemi Covid-19. Jurnal Teknologi Pendidikan, 22(1), 65-70. https://doi.org/10.21009/jtp.v22i1.15286.

Ibda, F. (2015). Perkembangan Kognitif: Teori Jean Piaget. Jurnal Intelektualita, 3(1), 27-38.

Ilhami, R. S., \& Rimantho, D. (2017). Penilaian Kinerja Karyawan dengan Metode AHP dan Rating Scale. Jurnal Optimasi Sistem Industri, 16(2), 150-157. https://doi.org/10.25077/josi.v16.n2.p150157.2017.

Imansari, N., \& Sunaryantiningsih, I. (2017). Pengaruh Penggunaan E-Modul Interaktif Terhadap Hasil Belajar Mahasiswa Pada Materi Kesehatan dan Keselamatan Kerja. VOLT: Jurnal Ilmiah Pendidikan Teknik Elektro, 2(1), 11-16. https://doi.org/http://dx.doi.org/10.30870/volt.v2i1.1478.

Jogezai, N. A., Baloch, F. A., Jaffar, M., Shah, T., Khilji, G. K., \& Bashir, S. (2021). Teachers' Attitudes Towards Social Media (SM) Use in Online Learning Amid The COVID-19 Pandemic: The Effects of SM Use by Teachers and Religious Scholars During Physical Distancing. Journal Heliyon, 7(4), 1-9. https://doi.org/10.1016/j.heliyon.2021.e06781.

Juwantara, R. A. (2019). Analisis Teori Perkembangan Kognitif Piaget Pada Tahap Anak Usia Operasional Konkret 7-12 Tahun dalam Pembelajaran Matematika. Jurnal Ilmiah Pendidikan Guru Madrasah Ibtidaiyah, 9(1), 27-34. https://doi.org/10.18592/aladzkapgmi.v9i1.3011.

Koderi. (2017). Pengembangan Modul Elektronik Berbasis SAVI Untuk Pembelajaran Bahasa Arab. Jurnal Teknologi Pendidikan, 19(3), 206-223. 
Kusuma, J. W., \& Hamidah. (2020). Perbandingan Hasil Belajar Matematika Dengan Penggunaan Platform Whatsapp Group Dan Webinar Zoom Dalam Pembelajaran Jarak Jauh Pada Masa Pandemik Covid 19. Jurnal Ilmiah Pendidikan Matematika, 5(1), 97-106. https://doi.org/10.26877/jipmat.v5i1.5942.

Laksana, D. N. L. (2016). Miskonsepsi Dalam Materi IPA Sekolah Dasar. Jurnal Pendidikan Indonesia /, 5(2), 166-175. http://dx.doi.org/10.23887/jpi-undiksha.v5i2.8588.

Logan, R. M., Johnson, C. E., \& Worsham, J. W. (2021). Development of an E-learning Module to Facilitate Student Learning and Outcomes. Teaching and Learning in Nursing, 16(2), 139-142. https://doi.org/10.1016/j.teln.2020.10.007.

Neppala, P., Sherer, M. V., Larson, G., Bryant, A. K., Panjwani, N., Murphy, J. D., \& Gillespie, E. F. (2018). An Interactive Contouring Module Improves Engagement and Interest in Radiation Oncology Among Preclinical Medical Students: Results of a Randomized Trial. Practical Radiation Oncology, 8(4), e190-e198. https://doi.org/10.1016/j.prro.2018.01.001.

Ningsih, S. Y., \& Mahyuddin, N. (2021). Desain E-Module Tematik Berbasis Kesantunan Berbahasa Anak Usia Dini di Taman Kanak-Kanak. Jurnal Obsesi : Jurnal Pendidikan Anak Usia Dini, 6(1), 137-149. https: //doi.org/10.31004/obsesi.v6i1.1217.

Noroozi, O., \& Mulder, M. (2017). Design and Evaluation of a Digital Module with Guided Peer Feedback for Student Learning Biotechnology and Molecular LifeSciences, Attitudinal Change, and Satisfaction. Biochemistry and Molecular Biology Education, 45(1), 31-39. https://doi.org/10.1002/bmb.20981.

Pratama, F., Firman, \& Neviyarni. (2019). Pengaruh Motivasi Belajar IPA Siswa Terhadap Hasil Belajar Di Sekolah Dasar Negeri 01. Jurnal Ilmu Pendidikan, 1(3), 280-286. https://doi.org/10.31004/edukatif.v1i3.63.

Purnomo, H., \& Wilujeng, I. (2016). Pengembangan Bahan Ajar dan Instrumen Penilaian IPA Tema Indahnya Negeriku Penyempurnaan Buku Guru dan Siswa Kurikulum 2013. Jurnal Prima Edukasia, 4(1), 67-68. https://doi.org/10.21831/jpe.v4i1.7697.

Puspita, L. (2019). Pengembangan Modul Berbasis Keterampilan Proses Sains Sebagai Bahan Ajar Dalam Pembelajaran Biologi. Jurnal Inovasi Pendidikan IPA, 5(1), $79-87$. https://doi.org/10.21831/jipi.v5i1.22530.

Qazi, A., Qazi, J., Naseer, K., Zeeshan, M., Qazi, S., Abayomi-alli, O., Ahmad, I. S., Darwich, M., Talpur, A., Hardaker, G., Naseem, U., Yang, S., \& Haruna, K. (2021). Adaption of Distance Learning to Continue the Academic Year Amid COVID-19 Lockdown. Journal Pre-Proofs (Children and Youth Services Review), 1-20. https://doi.org/10.1016/j.childyouth.2021.106038.

Rostikawati, D. A., \& Permanasari, A. (2016). Rekonstruksi Bahan Ajar Dengan Konteks Socio-Scientific Issues Pada Materi Zat Aditif Makanan Untuk Meningkatkan Literasi Sains Siswa. Jurnal Inovasi Pendidikan IPA, 2(2), 156-164. https://doi.org/10.21831/jipi.v2i2.8814.

Rubini, B., Permanasari, A., \& Yuningsih, W. (2018). Learning Multimedia Based on Science Literacy on the Lightning Theme. Jurnal Penelitian Dan Pembelajaran IPA, 4(2), 89-104. https://doi.org/10.30870/jppi.v4i2.3926.

Saripudin, E., Sari, I. J., \& Mukhtar, M. (2018). Using Macro Flash Animation Media on Motion Material to Improve Learning Achievement for Learning Science in Junior High School. Jurnal Penelitian Dan Pembelajaran IPA, 4(1), 68-75. https://doi.org/10.30870/jppi.v4i1.3316.

Setiyani, Putri, D. P., Ferdianto, F., \& Fauji, S. H. (2020). Designing a Digital Teaching ModuleBased on Mathematical Communication in Relation and Function. Journal on Mathematics Education, 11(2), 223-236. https://doi.org/10.22342/jme.11.2.7320.223-236.

Sidiq, R., \& Najuah. (2020). Pengembangan E-Modul Interaktif Berbasis Android Pada Mata Kuliah Strategi Belajar Mengajar. Jurnal Pendidikan Sejarah, 9(1), 1-14. https://doi.org/https://doi.org/10.21009/JPS.091.01.

Suarsana, I. M., \& Mahayukti, G. A. (2013). Pengembangan E-Modul Berorientasi Pemecahan Masalah Untuk Meningkatkan Keterampilan Berpikir Kritis Mahasiswa. Jurnal Pendidikan Indonesia, 2(2), 264-275. http://dx.doi.org/10.23887/jpi-undiksha.v2i2.2171.

Sulthon, S. (2017). Pembelajaran IPA Yang Efektif dan Menyenangkan Bagi Siswa Madrasah Ibtidaiyah (MI). ELEMENTARY: Islamic Teacher Journal, https://doi.org/10.21043/elementary.v4i1.1969.

Suryanda, A., Ernawati, \& Maulana, A. (2016). Pengembangan Modul Multimedia Mobile Learning Dengan 
Android Studio 4.1 Materi Keanekaragaman Hayati Bagi Siswa SMA Kelas X. BIOSFER: Jurnal Pendidikan Biologi (BIOSFERJPB), 9(1), 55-64. https://doi.org/10.21009/biosferjpb.9-1.9.

Susilowati, S. (2017). Pengembangan Bahan Ajar IPA Terintegrasi Nilai Islam untuk Meningkatkan Sikap dan Prestasi Belajar IPA Siswa. Jurnal Inovasi Pendidikan IPA, 3(1), 78-88. https://doi.org/10.21831/jipi.v3i1.13677.

Suzuki, S. N., Akimoto, Y., Suzuki, K., Okada, A., Hirata, K., Kato, T., Yajima, K., Kanematsu, H., Fukumoto, T., \& Yoshikawa, F. (2020). Development of A-txt system compatible introductory teaching materials for Electric Power Engineering using gaming simulation. Procedia Computer Science, 176, 15571566. https://doi.org/10.1016/j.procs.2020.09.167.

Syahroni, M. W., Dewi, N. R., \& Kasmui. (2016). The Effect of Using Digimon (Science Digital Module) with Scientific Approach at the Visualization of Students' Independence and Learning Results. Jurnal Pendidikan IPA Indonesia, 5(1), 116-122. https://doi.org/10.15294/jpii.v5i1.5800.

Taqiyyah, S. A., Subali, B., \& Handayani, L. (2017). Implementasi Bahan Ajar Sains Berbahasa Inggris Berbasis Metakognitif Untuk Meningkatkan Kemampuan Pemecahan Masalah Siswa SMP. Jurnal Inovasi Pendidikan IPA, 3(2), 224-234. https://doi.org/10.21831/jipi.v3i2.14859.

Wijayanti, N. P. A., Damayanthi, L. P. E., Sunarya, I. M. G., \& Putrama, I. M. (2016). Pengembangan E-Modul Berbasis Project Based Learning Pada Mata Pelajaran Simulasi Digital Untuk Siswa Kelas X Studi Kasus di SMK Negeri 2 Singaraja. Jurnal Pendidikan Teknologi Dan Kejuruan, 13(2), 184-197. https://doi.org/ 10.23887/jptk-undiksha.v13i2.8526. 